\title{
INNOVATIVE APPROACH IN THE DEVELOPMENT OF CULTURAL TOURISM IN THE MUNICIPALITY OF GEVGELIJA
}

\author{
Magdinceva-Sopova Marija', \\ Postolov Kiril2, \\ Elenov Riste ${ }^{3}$, \\ Magdalena Miceva ${ }^{4}$
}

${ }^{1}$ Faculty of tourism and business logistics-Gevgelija, University Goce Delcev-Stip, Republic of Macedonia 2Faculty of Economics-Skopje, University St.Cyril and Methodius, Republic of Macedonia

${ }^{3}$ Faculty of Agriculural Science and Food-Skopje, University St.Cyril and Methodius, Republic of Macedonia

${ }^{4}$ Master's student, Faculty of tourism and business logistics-Gevgelija, University Goce Delcev-Stip, Republic of Macedonia

Correspondence: Magdinceva-Sopova Marija e-mail: marija.magdinceva@ugd.edu.mk

\begin{abstract}
:
Developing the cultural tourism on a local, regional and national level depends on the already existing culture, cultural events and cultural heritage of a particular region. The Municipality of Gevgelija has various forms of cultural heritage such as natural, authentic and traditional resources, which represent the basics and gives the town a huge potential for the development of the cultural tourism. The purpose of this paper is to explain the importance of the innovative approaches in the development of the cultural tourism in the Municipality of Gevgelija, especially in today's era of innovation and digitalization. The survey will confirm our hypothesis that the municipality of Gevgelija is mainly recognized by tourists for its gambling tourism. The following hypothesis derives from the original hypothesis: Visitors and tourists cannot recognize the tourist products and the services and especially the cultural events and values that the Municipality of Gevgelija can offer in the original tourist offer.
\end{abstract}

\section{Keywords:}

cultural values, tourist offer, innovation, digitization

\section{INTRODUCTION}

Tourism is one of the most important and fastest growing industrial sectors recognizable for the $21^{\text {st }}$ century. In order to stimulate the national economy and to nurture the national and cultural heritage we need to come up with an appropriate tourist offer and to work on the tourism development. The impact of cultural events and heritage in the cultural tourism development is reflected through different output values and generates multiply effects that directly or indirectly contribute to the income increase on the local, regional and national level.

The Municipality of Gevgelija is located in the most southern part of The Republic of Macedonia, at an altitude of 64 meters and an area of $452 \mathrm{~km} 2$. In the municipality of Gevgelija there are 22.998 residents, of which around 15.700 residents live in the town and the rest of them live in 17 rural settlement places. Although being a very small town, the Municipality of Gevgelija has to offer a lot of cultural values and treasures that have been built in the past centuries. There are not a lot of written scientific papers in the professional literature that is dealing with innovative ways of working in the process of cultural tourism development. 
"Drucker (2005) said that the innovative ways of working encourage processes to create a new original travel offer, while entrepreneurship encourages the process of creating a tourist offer and the concept of innovative approach enables the discovery and exploitation of development potentials."

A successful enterprise operation depends on the constant introduction of new ways and forms of work and on the improvement of existing business processes that actually represent the concept of innovative approach. (Magdinceva Sopova et al. 2017)

Using digital models of operation and information technology improves the operation and reduces the time for transmission and exchange of information. Latest researches show that more than half of the people that are traveling are using the option to pay online and use the sales and booking system. The starting point for creating an original tourist offer and creating a new original approach in promoting the Municipality of Gevgelija as a recognizable area is the originality of the cultural values, heritage and cultural events.

This imposes the need for an integrated approach and synergy in the creation of content and information on the state of cultural tourism on the one hand using modern digital tools and technology and the promotion of cultural tourism which is of great importance for the creation of revenues from this sector.

\section{INNOVATIVE APPROACH OF ENTREPRENEURSHIP AS AN INNOVATIVE CONCEPT IN OPERATION}

Contemporary entrepreneurship is a development concept that enables the acquisition and retention of a competitive advantage.

Modern entrepreneurship involves the representation of one of the following elements:

- New forms of work;

- New resources;

- New customers;

- New service offer;

- Innovative cultural behavior;

- Organizational changes;

- Changes in the way of thinking among the participants in the business processes;

"Shanker (2008) said that the modern entrepreneurship as the process of implementing new trends at work encourages the subjects to think about taking advantage of opportunities".

Entrepreneurial behavior and encouragement of entrepreneurial organizational culture enables the entities to improve their performance (Magdinceva Sopova et al., 2015). The starting point for creating and maintaining a competitive advantage consists in the ability to encourage entrepreneurial behavior and focus on changes and market demands. Innovative activities in the business sector can be implemented only by subjects that have a positive attitude towards constant work changes, modern entrepreneurial approach and subject that apply original work processes. Enterprises that practice the concept of corporate entrepreneurship encourage employees to aim towards creative and innovative behavior. Innovation is a specific entrepreneurial tool that uses resources from new capabilities to create wealth (Reynolds, 2001).

\section{METHODOLOGY OF THE RESEARCH}

We conducted a practical research that was consisted of a questionnaire regarding 5 issues, to one-hundred and fifteen visitors in the city of Gevgelija of which one-hundred respondents agreed to take the survey and showed interest in answering the questions from the questionnaire, in order for them to understand the offer in the field of cultural tourism.

The research was conducted in the period from 01/01/2018 until 30/06/2018 and the questions were presented in order to give a clear image of whether the visitors are informed about the cultural events and the wide range of offers that as a tourist destination Gevgelija has to offer. 


\section{RESULTS OF THE RESEARCH}

After the research and sublimation of the received answers, it was concluded that the survey questionnaire that was the subject of research was responsible for 100 respondents, who actively participated in the research.

According to the received answers to each question, it is concluded that the first question - What do you recognize Gevgelija as a tourist destination? and possible answers to the same- a) location; b) gastronomy; c) casino tourism; d) sports tourism; e) shopping tourism e) health tourism h) natural beauties.

After reviewing the received feedback from the one-hundred participants that took part in the questionnaire it was concluded that eighty-five participants answered that Gevgelija is a synonym for casinos, while eleven participants answered that Gevgelija is an association for health care and only four participants answered that Gevgelija is a shopping destination. The results are graphically shown in Figure 1.

Figure 1. The results of the question - What do you recognize Gevgelija by?
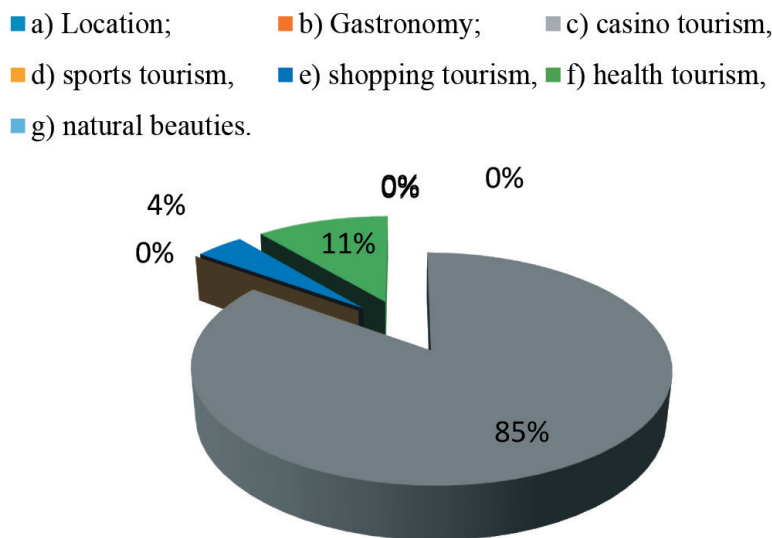

Source: Own research

To the next question - How many times have you visited Gevgelija so far? - a) Never b) 1-3 times c) 3-5 times $\mathrm{d}$ ) over 5 times- after reviewing the received feedback from the one-hundred participants that took part in the questionnaire it was concluded that seventy-three participants have visited the destination more than five times, eleven visitors have visited Gevgelija one to three times, while ten visitors visited Gevgelija three to five times and only six visitors have never visited the destination. The results are graphically shown in figure 2 .

Figure 2. The results of the question - How many times have you visited Gevgelija up till now?

$\square$ a) once, $\square$ b) 1-3 times, $\square$ c) 3-5 times, $\square$ d) over 5 times.

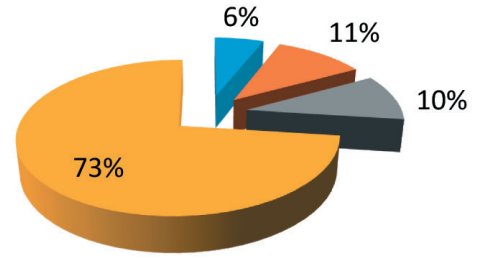

Source: Own research

When asked Would you visit Gevgelija again, all respondents or exactly 100 respondents said they would re-select the destination for the visit. Figure 3 shows graphically the results obtained. 
Figure 3. Graphs display the results of the question-Would you visit again the Municipality of Gevgelija?

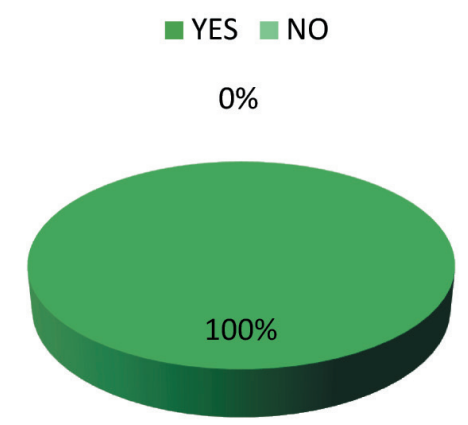

Source: Own research

To the next question - Are you well informed about the cultural events, festivals and exhibitions that take place in the Municipality of Gevgelija? most of the respondents are not informed, ie 92 people answered that they are not informed about the cultural events that take place in the Municipality and only 8 respondents have positively expressed their opinion on this issue.

Figure 4. The results of the question-Are you informed about cultural events, festivals, exhibitions, manifestations held in the Municipality of Gevgelija?

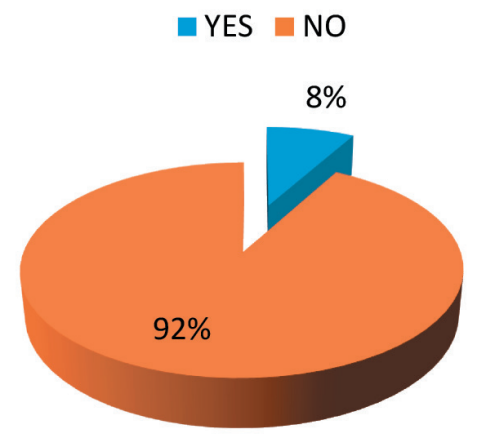

Source: Own research

To the question - How do you get informed about relevant information regarding the tourist offer of Municipality of Gevgelija?
a) friends
b) media
c) travel agency
d) internet
e) recommendation,

After reviewing the received feedback from the one-hundred participants that took part in the questionnaire it was concluded that sixty participants are using the internet for obtaining information, while twenttwo people receive their information through the media and only eighteen people get there information from friends. 
Figure 5. The results of the question-How are you informed about the tourist offer of the Municipality of Gevgelija?

$$
\begin{array}{ll}
\text { घa) friends, } & \square \text { b) media, } \\
\square \text { d) Internet, } & \square \text { e) recommendation. }
\end{array}
$$

$0 \%$

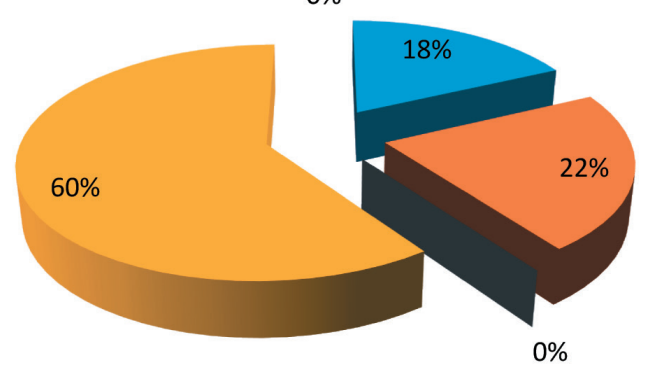

Source: Own research

\section{CONCLUSION}

The Republic of Macedonia has to offer a wild range of cultural values, especially in the cultural tourism sector. By developing and shaping a tourist offer, the Municipality of Gevgelija can be seen as a real potential in the process of developing the cultural tourism as well as the overall development. A complete tourist offer includes a detailed elaboration and development of a complex system of motives and models formed through complementary offers on several levels, in which all segments of the tourist product are elaborated in more detail (Dimitrov, 2010).

The results of the conducted research indicates that is of great significance to encourage the development of the cultural tourism, by promoting the most common types of cultural values, events and by promoting the cultural heritage in the area of Municipality of Gevgelija, using the innovative and digital forms of work.

The obtained information is a clear confirmation to our previous hypothesis, that Gevgelija is only seen as a "Gambling destination" by the tourists and that the foreign visitors do not recognize the cultural events, products nor services that Municipality of Gevgelija is authentic for. By combining the elements or components of the tourist destination, one or more tourism products can be formed, which are a combination of several elements together (Križman Pavlović, 2008).

Innovative approach is a process that directs the subjects to think about taking advantage of the opportunities applying new forms and ways of working. Applying the information technology in operation facilities accelerates the process of transmission and the exchange of information.

In today's society the process of exchanging information is limitless. Therefore innovations and applying information technology are a key factor in every business field, including the field of cultural tourism. The results from the research are a clear confirmation that indicates that the visitors have tendencies to come back to Municipality of Gevgelija but unfortunately they are not informed about the cultural events and the conclusion that they get their information through the internet. In order to promote the cultural tourism development, it is necessary to apply an innovative approach in creating an appropriate business model for managing the cultural heritage that will contribute to the creation of a suitable tourist offer and the use of innovative digital tools for promotion of Gevgelija as a destination with developed cultural tourism. 


\section{REFERENCES}

Dimitrov, N. (2010). Kulturno nasledstvo. Gevgelija: Fakultet za turizam i biznis logistika.

Drucker, P. (2005). Upravljanje u novom društvu. Novi Sad: Adizes.

Križman Pavlović, D. (2008) Marketing turističke destinacije. Pula: Mikrorad.

Magdinceva S., M., Postolov, K., Pulevska, I., L., Josimovski, S., Josheski, D. (2015). Corporate entrepreneurship and increasing competitiveness with specific reference to the enterprises in R. Macedonia: International scientific conferences Challenges in business and economics Growth, Competition and Innovations, 1516 October 2015 (pp. 393-402), Nis, Faculty of Economics.

Magdinceva Sopova, M., Postolov, K., \& Elenov R. (2017). The modern entrepreneurship in the process of modern tourism development in the Republic of Macedonia and municipality of Gevgelija: The First International Scientific Conference The Challenges of Tourism and Business Logistics in the 21st Century ISCTBL 2017, 24-25 October 2017 (pp. 319-325). Stip, Faculty of tourism and business logistics.

Reynolds, P.D. (2001). Global Entrepreneurship Monitor. London: London Business School.

Shanker, D. (2008). ICT and Tourism Challenges and Opportunities, Humanities and Social Sciences. Guwahati: Indian Institute of Technology. 